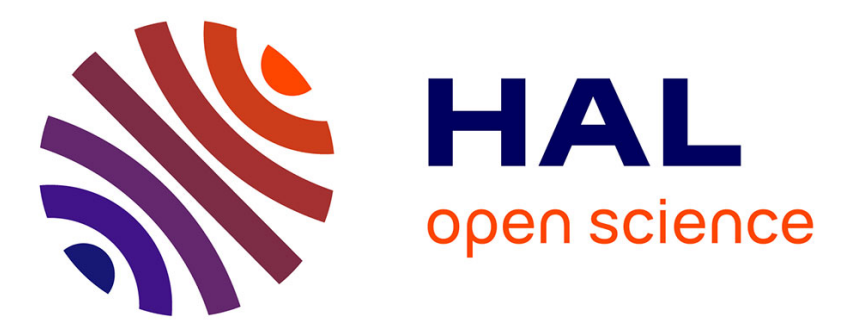

\title{
Toxic metals in urban runoff: physico-chemical mobility assessment using speciation schemes
}

Julio Flores-Rodrîguez, Anne-Laure Bussy, Daniel R. Thevenot

\section{To cite this version:}

Julio Flores-Rodrîguez, Anne-Laure Bussy, Daniel R. Thevenot. Toxic metals in urban runoff: physicochemical mobility assessment using speciation schemes. Water Science and Technology, 1994, 29 (1-2), pp.83 - 93. hal-01084567

\section{HAL Id: hal-01084567 \\ https://hal-enpc.archives-ouvertes.fr/hal-01084567}

Submitted on 19 Nov 2014

HAL is a multi-disciplinary open access archive for the deposit and dissemination of scientific research documents, whether they are published or not. The documents may come from teaching and research institutions in France or abroad, or from public or private research centers.
L'archive ouverte pluridisciplinaire HAL, est destinée au dépôt et à la diffusion de documents scientifiques de niveau recherche, publiés ou non, émanant des établissements d'enseignement et de recherche français ou étrangers, des laboratoires publics ou privés.

\section{(ㄷ)(1)}

Distributed under a Creative Commons Attribution| 4.0 International License 


\title{
TOXIC METALS IN URBAN RUNOFF: PHYSICO-CHEMICAL MOBILITY ASSESSMENT USING SPECIATION SCHEMES
}

\author{
J. Flores-Rodríguez*,**, A.-L. Bussy* and \\ D. R. Thévenot** \\ * Lab. de Bioélectrochimie et d'Analyse du Milieu (LABAM), Faculté de Sciences et \\ Technologie, Université Paris XII-Val. de Marne, Avenue du Général de Gaulle, \\ 94010 Créteil Cédex, France \\ ** Lab. de Electroquímica y de Especiación de Metales Pesados (LEEMP), División \\ de Ciencias Básicas e de Ingeniería, Departamento de Ciencias Básicas, \\ Universidad Auronoma Metropolitana-Azcapotzalco, 02200 México D.F., México
}

\begin{abstract}
Physico-chemical characterization of lead, zinc and cadmium has been carried out on eight samples from both separate and combined sewers. Dissolved and particulate total metal levels have been determined. A speciation scheme has been used to further divide these phases in two dissolved fractions, bioavailable and stable, and five particulate fractions, ion-exchangeable, acid-soluble, reducible, oxidizable and residual. Total dissolved lead concentrations were found to be largely below European Community (EC) directives for drinking water production. Lead was represented by stable forms while zinc and cadmium were mainly bioavailable. Particulate concentrations were higher than natural levels found in the Seine-Normandie basin. Zinc was characteristic for municipal effluents, and lead and cadmium were more concentrated in separate sewers. Correlations have been observed between particulate heavy metals and volatile matter on the ring highway, or with iron at the Savigny site. The particulate metal speciation scheme has demonstrated the important dependence of heavy metal distribution on the sampling site, as well as the potentially more mobile nature of zinc and cadmium, compared to that of lead. The structural modifications undergone by solids during their transport along the sewer networks had a significant impact on particulate metal mobility. This has been clearly noted for lead, whose mobility decreased from upstream to downstream in the studied system.
\end{abstract}

\section{KEYWORDS}

Heavy metals; pollution; impact; storm sewer overflow; combined sewer overtlow; detention pond; sediment; speciation.

\section{INTRODUCTION}

Originally, only hydraulic impacts of urban runoff were considered and assessed for waste wate management. During the last decade, it has been demonstrated that roof runoff (Förster, 1990), as well as highway runoff, contains high pollutant concentrations (Hémain, 1984; Torno et al., 1985). In fact, runoff appears to be the main problem in improving surface water quality in highly urbanised areas (Marsalek, 1991). Sewer suspended solids and sediments are especially interesting since a very large fraction of pollutants is fixed on them (Chebbo, 1992). In most cases, the particulate matter directly reaches surface 
waters by combined or separate sewer overflows. There, through transport and settling, they may pose a threat to the aquatic environment. In particular, solids attract toxic metals, i,e. zinc, lead, copper and cadmium, which may be released into the dissolved phase. Mobility and toxicity of these metals must be determined for assessing urban runoff impact on receiving waters and for developing suitable treatment procedures.

Different kinds of experimental approaches have been developed to study metal transport and biogeochemical cycling processes, as well as to predict their biological impact, with acute or long term effect studies (Allen et al., 1980; Nelson and Donkin, 1985). Field measurements of river suspended solids and sediments surrounding sewer overflows give direct indications of the total amount of heavy metal pollution introduced into the receiving system and its accumulation by sedimentation in river beds (Estèbe, 1993). Caged or free bioindicators have also been utilized to determine sewer overflow toxicity (Shutes et al., 1990; Fraboulet $e t$ al., 1993). Laboratory assays, like sediment re-suspension experiments in a reactor, can also yield interesting data on the release capacities of polluted particles (Lebreton et al., 1993, Bussy, 1993). Finally, numerous physico-chemical speciation schemes have been developed to give indications of the heavy metal distribution in sediments and waters (Florence, 1982; Welte and Montiel, 1983). It is well known that exact species determination in aqueous and solid environmental samples is excessively difficult because of the complexity of natural systems, and that heavy metal physico-chemical speciation schemes cannot really extract well defined fractions, because of sample handling mistakes (Kersten and Förstner, 1987), non-specific reactions to particular mineral or organic fractions (Megellati, 1982), or metal redistribution during the fractionation procedure (Ajayi and Vanloon, 1989). However, the data obtained from these schemes are considered as operational (Martin et al., 1987) and provide useful information on the relative mobility and bioavailability of toxic metals (Morisson et al., 1989; Bourg et al., 1992).

This paper presents some of the results obtained during a three year study of storm sewer discharges. The heavy metal speciation scheme included both dissolved and particulate elements (Flores-Rodriguez et al., 1990). The particulate part, slightly modified from Tessier et al. (1979), consisted of five fractions. The dissolved part was simpler, with a unique organic resin extraction (Figura and McDuffie, 1977) as close as possible to the biological membrane uptake. A wide range of situations was reviewed, with pure road runoff, as well as combined sewer overflows, separate sewers, and wet and dry detention ponds.

\section{SAMPLING SITES}

TABLE 1. Main Site Characteristics: Liquid and Particulate Samples

\begin{tabular}{|c|c|c|c|c|c|c|c|c|}
\hline \multirow[t]{2}{*}{$\begin{array}{c}\text { Sample } \\
\text { Reference }\end{array}$} & \multirow[t]{2}{*}{$\begin{array}{l}\text { Sampling } \\
\text { Site }\end{array}$} & \multirow[t]{2}{*}{$\begin{array}{l}\text { Sampling } \\
\text { Date }\end{array}$} & \multirow[t]{2}{*}{$\begin{array}{l}\text { Sewer } \\
\text { Type }\end{array}$} & \multirow[t]{2}{*}{$\begin{array}{l}\text { Catchment } \\
\text { Type }\end{array}$} & \multirow{2}{*}{$\begin{array}{c}\text { Catchment } \\
\text { Area } \\
\text { (ba) }\end{array}$} & \multirow{2}{*}{$\begin{array}{c}\text { Rain } \\
\text { Intensity } \\
(\mathrm{mm} / \mathrm{h})\end{array}$} & \multicolumn{2}{|c|}{$\begin{array}{c}\text { Number of } \\
\text { Saniples }\end{array}$} \\
\hline & & & & & & & Liquid & Part. \\
\hline 1 & Ring highway & May 89 & & road & 3 & n.a. & 0 & 9 \\
\hline $2_{p}, 2_{s}$ & Savigny pond, sewer & Mar 89 & $\mathrm{~S}$ & urban & 500 & 1.3 & 8 & 8 \\
\hline 3 & Créteil Lake SSO & Sep 89 & S & urb+shop & 75 & n.a. & 1 & 1 \\
\hline 4 & La Morée sewer & Mar 89 & S & very urban & 1,300 & 1.3 & I & 1 \\
\hline 5 & Béquigneaux pond & Oct 89 & $S$ & urh+indust & 606 & 4.4 & 6 & 13 \\
\hline 6 & La Molette pond & Aug 89 & $\mathrm{C}$ & urban & 8,000 & $5-13$ & 7 & 11 \\
\hline 7 & La Molene pond & Aug 91 & C & urban & $8,000)$ & 1.2 & 4 & 9 \\
\hline 8 & Clichy CSO & Jul 91 & $\mathrm{C}$ & very urb & 12,000 & n.a. & 0 & 1 \\
\hline
\end{tabular}

n.a. = not available; $\mathrm{S}=$ separate $\quad \mathrm{C}=$ combined $;$ Par. $=$ particulate .

Eight sewer flows, following storm events, were studied at seven different sites, most of them near Paris. Table 1 shows the principal site characteristics. The storm outlet of a portion of the Paris ring highway was chosen as a road runoff sample. La Morée separate sewer carries waters from a part of Seine-Saint-Denis 
county, a northern Paris suburb, as well as the Sausset, which also has an outfall in the wet detention pond of Savigny. La Molette dry detention pond is located in the same county but receives combined waters. Two storms of different intensities were studied at this site. South of Paris, Créteil Lake is used as a wet detention pond for a separate sewer draining the town and, particularly, an important shopping centre. The most important overflow of the combined sewer draining Paris and some of the surrounding towns is located at Clichy. Béquigneaux dry detention pond is the only site situated in the Bordeaux area, in the South of France, having a different soil type, and with some industrial inputs into its separate sewer system.

\section{LABORATORY ANALYSES}

Laboratory samples were split into dissolved and particulate phases using a $30 \mathrm{~min} 6000 \mathrm{~g}$ centrifugation (Jouan, model Plasma R 1000), followed by a tangential membrane filtration (Millipore, model Minitan S) using $0.45 \mu \mathrm{m}$ Millipore Durapore membranes. Total dissolved lead, zinc and cadmium were determined directly by furnace atomic absorption spectrophotometry (AAS) with a HGA 700 Perkin Elmer spectrophotometer and an AS 70 autosampler. The bioavailable fraction was extracted by a chelating resin 24 hour contact. The chosen resin. Chelex 100, had previously been transformed into its calcium form by means of a $1 \mathrm{M} \mathrm{CaCl}_{2}$ solution as indicated by Figura and McDuffie (1977). It was estimated to be one of the closest resins to biological membrane uptake, except for S-compounds (Morrison et al., 1989). Stable dissolved metals were measured by AAS in the resin-extracted sub-sample supernatants. Bioavailable metals were determined by subtracting stable fractions from total dissolved levels (Flores-Rodríguez et al., 1990).

Total particulate metals were determined by flame or furnace AAS, after an acid digestion by a mixture of concentrated $\mathrm{HNO}_{3}$ and $\mathrm{HClO}_{4}$. The sediment samples also underwent a chemical speciation, using a five successive extraction speciation scheme adapted from Tessier et al. (1979) by Flores-Rodríguez (1992). Following the extraction order, these fractions were:

- ion exchangeable, obtained after a $1 \mathrm{M} \mathrm{CH}_{3} \mathrm{COONH}_{4}$ extraction at $\mathrm{pH} 7$ and room temperature, during 2 hours,

- acid-soluble, obtained after a $1 \mathrm{M} \mathrm{CH}_{3} \mathrm{COOH} / \mathrm{CH}_{3} \mathrm{COONa}$ extraction, at $\mathrm{pH} 5$ and room temperature, during 2 hours,

- reducible, obtained after a $0.04 \mathrm{M} \mathrm{NH}_{2} \mathrm{OH}, \mathrm{HCl}$ in $25 \% \mathrm{CH}_{3} \mathrm{COOH}$ extraction, at $\mathrm{pH} 2$ and $85^{\circ} \mathrm{C}$ during 5 hours,

- oxidizable, obtained after a 3 hour $30 \% \mathrm{H}_{2} \mathrm{O}_{2}$ in $0.02 \mathrm{M} \mathrm{HNO}_{3}$ extraction at $96^{\circ} \mathrm{C}$, in a water bath,

- residual, obtained after the addition of a $\mathrm{HNO}_{3} / \mathrm{HClO}_{4}$ concentrated mixture, evaporation to dryness on a hot plate, and a second extraction with $15 \% \mathrm{HNO}_{3}$ under a slight heating.

\section{RESULTS AND DISCUSSION}

\section{Dissolved Metals}

Table 2 displiys mean lead, zinc and cadmium concentrations in seven dissolved samples collected during, or just after, storm events. Levels stayed usually below or near surface water EC directives for drinking water production (EC Dir, 80/778). The total dissolved metals appeared to be much smaller than values previously measured in Paris urban area (STU, 1985). However, it may be important to notice that these latter data were obtained with bulk waters firstly aciditied and then filtered, allowing possible metal release from suspended solids into the final dissolved samples.

The extraction carried out with the chelating resin revealed that cadmium and zinc were mostly found in bioavailable form in separate and combined water samples, whereas the majority of lead was often stable (Fig. 1). The different pattern observed for Cléteil lake may be due to its wet detention pond status, as well 
as its large surface ( 40 ha versus 4 ha for Savigny pond) which tends to favour the influence of the groundwater. By comparing sewer metal concentrations to pond levels at Savigny site (samples $2_{S}$ and $2_{p}$ ), a purification capacity of this pond for dissolved metals was observed, especially for zinc and lead. For the same storm event as the studied one on Savigny site (but for a larger catchment area). La Morée sewer (sample 4) displayed much higher zinc levels. If total lead and cadmium concentrations were slightly lower, their relative bioavailable fractions were increased. The storm intensity did not modify the total levels of lead and cadmium at La Molette site. However, their bioavailable fractions were more important for a smal.] rain (sample 7) than for a big stom (sample 6). Among the three metals, zinc was the most affected by rainfall intensity, with an observed doubled bioavailable fraction. Finally, Béquigeaux dry detention pond (sample 5) displayed similar patterns to sites in Paris, except for the cadmium level of its dissolved samples, which was strongly increased by industrial inputs.

TABLE 2 Values of Total Dissolved Metals in Sewer Water Samples

\begin{tabular}{|c|c|c|c|}
\hline \multirow{2}{*}{$\begin{array}{c}\text { Sample } \\
\text { Reference }\end{array}$} & \multicolumn{3}{|c|}{ Dissolved Metal $(\mu g / 1)^{\circ}$} \\
\hline & $\mathrm{Pb}$ & $\mathrm{Zn}$ & $\mathrm{Cd}$ \\
\hline $2 p$ & 3.0 & 3.5 & 0.7 \\
\hline $2 s$ & 17.8 & 11.9 & 0.9 \\
\hline 3 & 8.6 & 29.0 & 0.4 \\
\hline 4 & 12.7 & 53.0 & 0.8 \\
\hline 5 & $9.6 \pm 0.6$ & $14.0 \pm 8.0$ & $1.4 \pm 0.4$ \\
\hline 6 & $6.1 \pm 1.9$ & $28.7 \pm 1.1$ & $0.4 \pm 0.1$ \\
\hline 7 & $6.6 \pm 1.6$ & $56.0 \pm 1.4$ & $0.3 \pm 0.3$ \\
\hline S.T.U. Measurements ${ }^{x}$ & $200-1100$ & $500-1900$ & $5-50$ \\
\hline Drinking Water Production (EC dir.) ${ }^{*}$ & 50.0 & 50.0 & 1.0 \\
\hline
\end{tabular}

${ }^{x}$ from S.T.U. (1985); ${ }^{*}$ Surface Water Quality EC Directives for Drinking Warer Production (80/778)

- for multiple sample sites, mean \pm standard deviation (see text for sample identification)
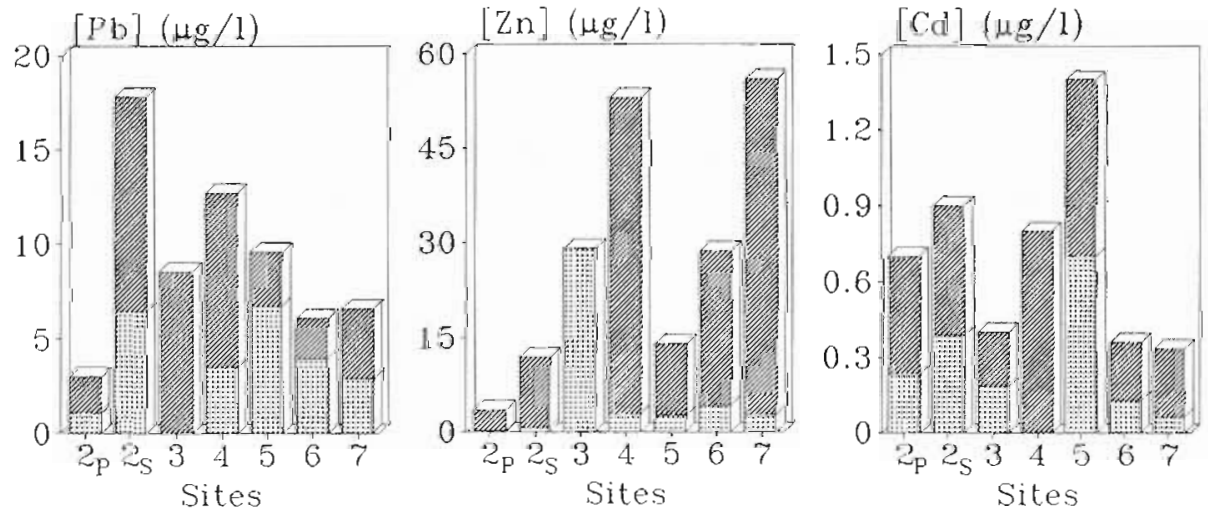

Fig. 1. Distribution ol dissolved $\mathrm{Pb}, \mathrm{Cd}$ and $\mathrm{Zn}$ between bicavailable and stable fraclions. (sce text lor sample kdentification) with lractions: viturtung bicavailable, stable.

\section{$\underline{\text { Particulate Metals }}$}

The automobile's impact on heavy metal pollution high lead and cadmium concentrations of runoff suspended solids - sample 1 ) is clearly demonstrated in Table 3. Another study of the sume portion of Paris ring highway, focused $n$ rnad tunnel aerosols, supports this observation (Lebreton et al. 1992). It showed 
higher particulate metal levels than our analysis, as well a significant tendency to leach out, which could be attributed to its lack of water contact. Particulate lead and cadmium are also carried down to Créteil Lake SSO (sample 3) from a catchment area which principally consists of an important shopping centre and its extensive car park areas, the latter exerting an important influence on sewer effluent quality. A battery production plant was identified in the Béquigneaux detention pond catchment area (sample 5) which explains the high levels of cadmium and zinc found in this sample. Savigny and La Morée separate sewers (samples $2_{S}$ and 4) showed lower heavy metal concentrations than combined sewer samples taken from the same area. The combined sewer sample levels did not vary significantly with catchment area (Clichy - sample 8), with a concentration very similar to La Molette, but for a much larger drained surface. Particulate lead and cadmium concentrations were similar for separate and combined samples. By contrast, zinc levels were notably more important on combined sewer sites, as well as less variable among the storm events. A study of French combined sewage metal composition (Colin, 1986) has shown that zinc is the heavy metal which is the most important in flow coming into a sewage plant, by at least a factor 4 . Thus, when a notable storm event occurred, runoff solids, drained by La Molette combined sewer, produced a dilution of the particulate zinc concentration normally found in the municipal sewage effluent.

TABLE 3 Total Particulate Metal Concentrations in Samples and Associated Pollution Factors

\begin{tabular}{|c|c|c|c|c|c|c|c|c|}
\hline \multirow[t]{2}{*}{ Sample } & \multicolumn{4}{|c|}{ Particulate Metals (g/kg d.w.) } & \multicolumn{4}{|c|}{ Pollution Factor } \\
\hline & $\mathrm{Pb}$ & $\mathrm{Zn}$ & $\mathrm{Cd}$ & $\mathrm{Fe}$ & $\mathrm{Pb}$ & $\mathrm{Zn}$ & $\mathrm{Cd}$ & $\mathrm{Fe}$ \\
\hline I & 2.36 & 1.11 & 0.013 & 29 & 79 & 11 & 26 & 2 \\
\hline${ }^{2} s$ & 0.23 & 0.38 & 0.003 & 14 & 8 & 4 & 6 & 1 \\
\hline $2_{\mathrm{p}}^{3}$ & 0.05 & 0.11 & $<0.001$ & 7 & 2 & 1 & 1 & 1 \\
\hline 3 & 3.18 & 1.76 & 0.021 & 30 & 106 & 18 & 42 & 2 \\
\hline 4 & 0.96 & 0.77 & 0.007 & 16 & 32 & 8 & 14 & 1 \\
\hline 5 & 0.46 & 3.85 & 0.795 & 38 & & & & \\
\hline 6 & 0.95 & 2.03 & 0.014 & 27 & 32 & 20 & 28 & 2 \\
\hline 7 & 0.36 & 2.67 & 0.009 & 11 & 12 & 27 & 18 & 1 \\
\hline 8 & 1.40 & 3.08 & 0.008 & 16 & 47 & 31 & 16 & 1 \\
\hline AFNOR regulation $^{\circ}$ & 0.30 & 3.00 & 0.015 & n.a. & & & & \\
\hline Natural levels ${ }^{\lambda}$ & 0.03 & 0.10 & $<0.001$ & 13 & & & & \\
\hline Circ. highway aerosol ${ }^{+}$ & 4.8 & 2.33 & 0.027 & 50 & & & & \\
\hline Down. Paris Seine sed. ${ }^{*}$ & 0.28 & 0.68 & 0.009 & 19 & & & & \\
\hline
\end{tabular}

Finally, most of our samples reach the river Seine. Considering the natural levels of Seine basin sediments, which have been statistically calculated (Pereira-Ramos. 1989 - Table 3), our results demonstrated that urban runoff and CSO outfalls may have a very negative influence on receiving water bodies. Thus, it should be useful to have suspended soliu separation treatment before the sewage reaches the river Seine. A recent study of the Seine sediment first layer, on a site located downstream from Paris and its main combined sewer outfalls supported this, showing great similarity to our samples and a significant increase of natural heavy metal levels (Estèbe et al., 1993). They imply a significant sewage impact on river sediment quality. Measured metal concentrations, particularly lead, often exceed allowed limits for agricultural use of solid waste (AFNOR U44-041/1975). If such solids were removed, using for instance dry detention ponds, the resulting sludge could not always be recycled. However, Savigny wet detention pond showed real purifying capacity, if effluent levels are compared with levels found in its connected sewer (samples $2_{p}$ and 2 s). Locial water authorities have defined a pollution factor for sediments, by dividing measured metal concentrations by calculated natural levels (Pereira-Ramos, 1989). This factor allowed us to more easily evaluate sediment heavy metal pollution, since natural soil concentration may vary significantly. depending on the site (Robbe, 1982). The right part of Table 3 displays pollution factors for lead, zinc, cadmium and iron for all our 
"Parisian" samples. One principal characteristic of separate sewer waters should be noted; the significant variability of their quality, which has been the argument for not treating these waters. Pollution factors calculated for combined sewers are more homogenous since they only vary from 12 to 47 , while the separate samples vary from 4 to 106 (except Savigny pond, which can be considered as unpolluted). Another remarkable fact is that iron levels were roughly constant among the samples, with a maximum pollution factor of 2. We can conclude that natural levels of this metal were found in our samples. This major soil characteristic can be considered as typical in the Seine basin, independent from the general heavy metal pollution level.

This property has allowed us to use iron as a natural mineral fraction tracer. At the same time, we chose the volatile matter ratio as the organic matter tracer, since it is generally utilized to measure the organic matter content of sewage effluents (AFNOR T90-029/1970). By plotting correlations between these two parameters and the heavy metal concentrations, we wanted to roughly distinguish the origin of metallic pollutants or, at least, their transport mode. These correlations are illustrated for zinc in Figure 2 . The relations between sites are clearly displayed on the graphs. Similar conclusions were made for lead and cadmium. Créteil sediment (sample 3) characteristics were consistent with the ring highway (sample I) results, probably because of the numerous parking areas included in the catchment area. La Morée (sample 4) was closer to Savigny (sample 2), which is located in the same county. The small rainfall we studied at La Molette pond (sample 7) presented some analogies with Clichy outfall (sample 8), but during an important storm event La Molette samples were more similar to the separate sewer samples collected in the same county at the Savigny and La Morée sites. The non-homogeneous repartition of solids in a dry detention pond was clearly notable within La Molette pond. The weak intensity of the small rainfall increased the phenomenon of selective settling which induces sampling representativity problems.
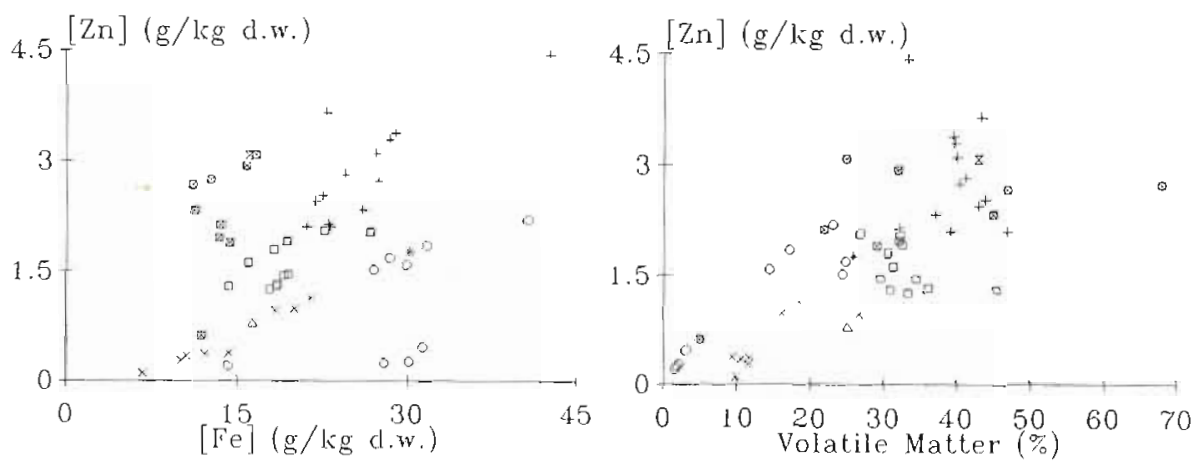

Fig. 2. Correlations between total particulate zinc and either total particulate iron, or volatile matter Sites: $0: 1, x: 2, *: 3, \Delta: 4,+: 5, \square: 6, \approx: 7, \mathbb{z}: 8$ (see text for sample identification)

Linear regressions were done on sample sites when possible. Correlation coefficients are listed in Table 4. Significant correlations were only found on two sites. Solids sampled in the runoff detention chamber of Paris ring highway (sample 1) indicated a strong link between heavy metal concentrations and volatile matter content. By contrast, Savigny pond (sample 2) metal levels showed a strong correlation with the level of particulate iron. The first site, typically representative of automobile pollution, may concentrate pollutants from organic materials like tyres, oils, etc. These products have also been listed by Morrison (1985) as important heavy metal sources. On the second site, sediment sumples showed a very strong correlation between iron and the three studied elements (correlation coefticients ranged from 0.83 to 0.95). This may be explained by the fact that location of the catchment area, nutside Paris and not very urban, favours the presence of soil particles rather than pure road runoff solids. Tessier et al. (1982) have also observed important correlations between iron and heavy metals for river sediments, as well as Brilhante (1990), for different types of solids. The relationship to volatile matter, although not as good as for the ring highway. 
was notable. This last revealed the impact of road runoff on the quality of these samples. However, the mineral nature of the source, or at least of the transport mode of heavy metals on this site, is more important. Although Béquigneaux (sample 5) is a separate sewer site like the two former, its sediments did not show good correlation with the two studied parameters. Particularly, lead did not show a relationship with iron, even though it is strongly bound to inorganic particles (Aualiitia and Pickering, 1987). The industrial outfall may create this difference by modifying deeply the sample characteristics.

La Molette large storm (sample 6) showed some links between heavy metals and iron, as well as volatile matter, like it was observed for Savigny pond. The small rainfall (sample 7), which occurred on the same site, presented the lowest correlation coefficient for both parameters. Thus, the nature and transport of the metallic pollutants in combined sewers is strongly dependent on storm event duration. A heavy rainfall gave results closer to separate sewer ones (like Savigny samples) than did small events. This difference between the storms at La Molette was verified by calculating the regression coefficients for all the samples which were collected on this site. We generally obtained lower values, except for lead (which links with iron), which was greater for both events.

TABLE 4 Correlation Coefficients $\left(r^{2}\right)$ for Particulate Heavy Metal Versus Volatile Matter and Iron Linear Regressions - Site by Site Study

\begin{tabular}{ccccc}
\hline Site Reference & Parameter & $\mathrm{Pb}$ & $\mathrm{Zn}$ & $\mathrm{Cd}$ \\
\cline { 2 - 5 } 1 & $\mathrm{VM}$ & 0.77 & 0.86 & 0.63 \\
$(\mathrm{n}=9)$ & $\mathrm{Fe}$ & 0.49 & 0.34 & 0.01 \\
& & & & \\
2 & $\mathrm{VM}$ & 0.55 & 0.65 & 0.57 \\
$(\mathrm{n}=8)$ & $\mathrm{Fe}$ & 0.92 & 0.95 & 0.83 \\
& & & & \\
5 & $\mathrm{VM}$ & 0.12 & 0.06 & 0.06 \\
$(\mathrm{n}=13)$ & $\mathrm{Fe}$ & 0.09 & 0.63 & 0.80 \\
6 & $\mathrm{VM}$ & 0.48 & 0.26 & 0.44 \\
$(\mathrm{n}=11)$ & $\mathrm{Fe}$ & 0.49 & 0.49 & 0.62 \\
7 & $\mathrm{VM}$ & 0.0003 & 0.38 & 0.89 \\
$(\mathrm{n}=9)$ & $\mathrm{Fe}$ & 0.54 & 0.19 & 0.00002 \\
& & & & \\
$6+7$ & $\mathrm{VM}$ & 0.008 & 0.18 & 0.26 \\
$(\mathrm{n}=20)$ & $\mathrm{Fe}$ & 0.70 & 0.02 & 0.43 \\
\hline
\end{tabular}

(see text for sample identification)

As these solids are discharged directly to the rivers, it was interesting to evaluate the portion of the particulate heavy metals which could be released to pollute the natural environment. Total metal cannot provide this kind of indication. With these sequential chemical extractions, physico-chemical sediment speciation may offer more information. We used this process upon some particulate samples. Figure 3 displays the distribution of heavy metals among the five fractions of the chosen scheme. Regardless of the sites or the metals, the most important fractions were the acid-soluble and reducible fractions, if the residual fraction was not taken into account. This latter introduced greater differences for lead and iron than for zinc and cadmium. Thus, these two latter heavy metals showed similar distributions, while the lead pattern appeared to be closer to iron. This may be linked to the good colrelations usually found between the total particulate concentrations of these two elements. Moreover, the Iarge particulate lead residual fraction implied that its stable nature may render it essentially non-toxic for the environment. In 1979, Wilber ef al. also found this metal mostly in residual forms in runoff waters. The ring highway (sample 1) was the only site where samples containing important ion-exchangeable fractions for all the metals were found. This agrees with previous work carried out on the same site, but with tunnel road aerosols (Lebreton and Thévenot, 1992), and with the study of Revitt ef al. (1987), which found that particulate lead in road runoff 
and gully pot outflow was mainly present in the ion-exchangeable fraction. In addition to this fraction, we found heavy metals in acid-soluble and reducible forms in our road runoff sample. However, the correlations previously plotted for this site displayed notable links between heavy metals and volatile matter, which is related to organic matter, destroyed with the oxidizable fraction.
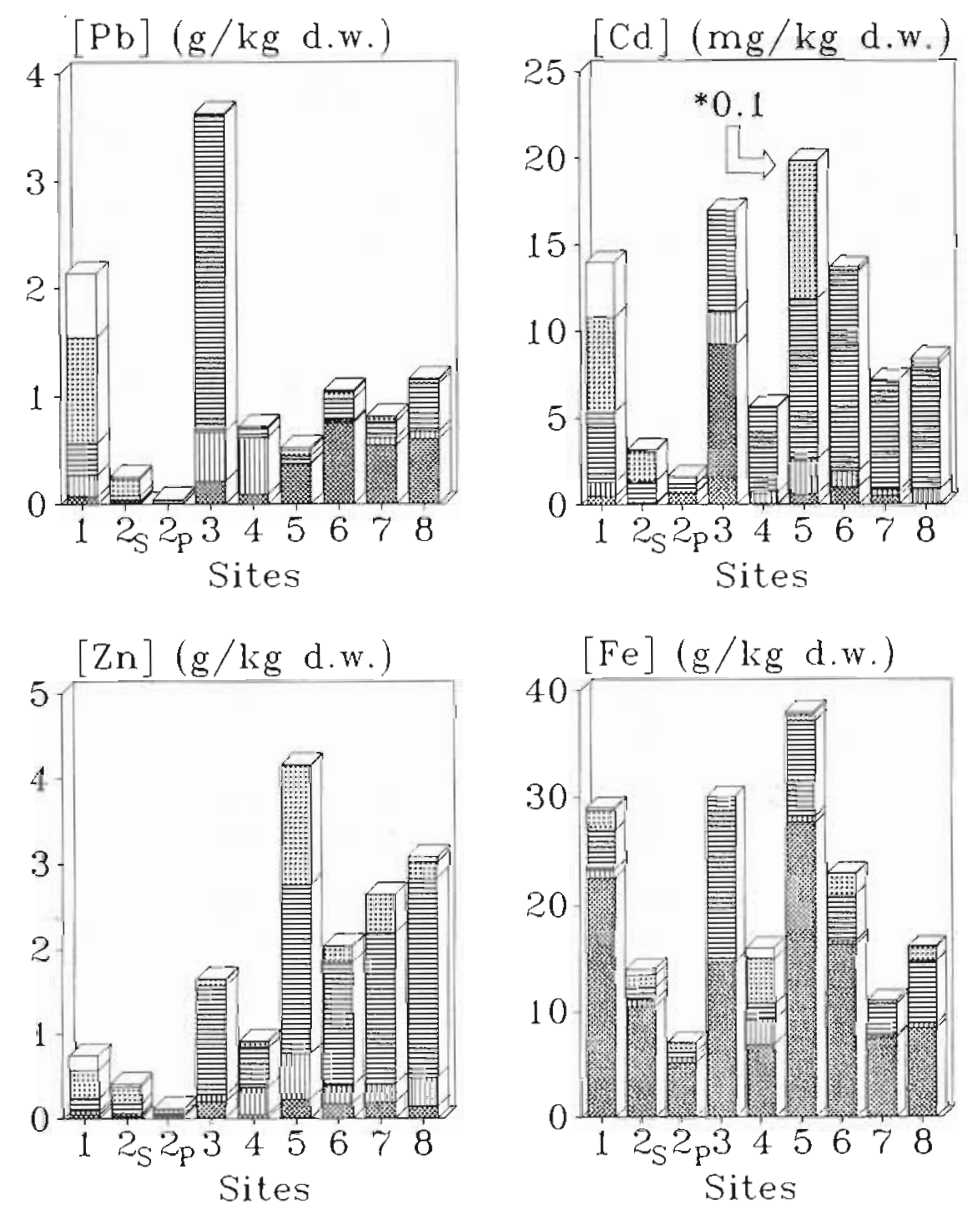

Fig. 3. Physico-chemical distribution of parliculate $\mathrm{Pb}, \mathrm{Cd}$ and $\mathrm{Zn}$.

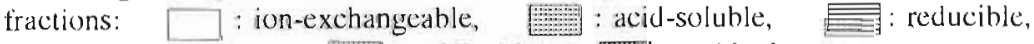

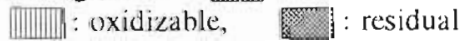
(sce text lor sample identification)

This discrepancy may be due to the reagent used for the extraction, based on the breaking down of humic acids/metals bonds, while heavy metals were more probably adsorbed on different organic matter with weaker chemical bonds. The Créteil Lake SSO (sample 3) was not as close to the ring highway sample as the correlations indicated. Particulate heavy metals were extracted primarily in more stable fractions. This could be explained by the sewer sample, which allowed an in-pipe evolution of sediments. The result differed from those obtained with longer separate sewers (samples 2 and 4), probably because of the short travel time.

A comparison of metal distributions in these samples, particularly with lead, indicates their progressive stabilization from upstream (road runoff) to downstream (the sewer system). The significant runoff processes in the larger catchment areas implied a greater suspended solids transport. These solids tend to be rich in 
humic organic matter, which may form more stable chemical bonds than with runoff from small catchment areas like Créteil. Finally, it is important to remark that for substantial metal concentrations, the largest fractions were most easily released (i.e. Créteil and Béquigneaux), while less concentrated samples had a large residual fraction.

\section{CONCLUSION}

Concentrations of dissolved lead, zinc and cadmium in separate and combined samples were generally below EEC water quality directives for sources of drinking water. In some cases, zinc and cadmium exceeded these values. Moreover, they were mostly found in bioavailable form, whereas lead was more stable. Particulate heavy metal concentrations varied over a wide range. All were much higher than natural levels calculated for the Seine-Normandie basin, and for measured Seine sediment levels, and higher than French regulations for residual metals in sludge used for agricultural recycling. Lead and cadmium were mainly found in runoff, but zinc was concentrated in municipal effluents diluted at the final outfall. Few correlations could be found between iron and volatile matter, except for very specific sites. Dry detention ponds presented very different results because of a kind of selective settlement which occurred during and after storms. It appeared that the structural modifications undergone by solids during their transport along the sewer networks had a significant effect on particulate heavy metal distributions (and their related mobilities). These were also very site-dependent. Runoff from roads and car parks showed significant metal mobility. Particulate pollutants were transformed during travel through the sewage network to more stable forms found in the detention ponds. This was particularly notable for lead, whose exchangeable forms disappeared, and whose residual fraction increased.

\section{ACKNOWLEDGMENTS}

Authors gratefully acknowledge the financial support of the Consejo Naciona] de Ciencia y Tecnología de México (CONACYT), the Direction de l'Equipment et de l'Assainissement of the Seine-Saint-Denis County (DEA 93), and the Agence de l'Eau Seine-Normandie, as well as the Plan Urbain.

\section{REFERENCES}

Ajayi, S.O. and Vanloon, G.W. (1989). Studies on redistribution during the analytical fractionation of metals in sediments. The Science of the Total Environment, 87/88, 171-187.

Allen, H.E., Hall, R.H. and Brisbin, T.D. (1980). Metal speciation - Effects on aquatic toxicity. Environmental Science and Technology, 14, 441-443.

Aualiitia, T.U. and Pickering, W.F.(I987). The specific sorption of trace amounts of $\mathrm{Cu}, \mathrm{Pb}$, and $\mathrm{Cd}$ by inorganic particulates. Water, Air, and Soil Pollution, 35, 171-185.

Bourg, A., Thévenot, D.R., Boutier, B. and Mouchel, J.-M. (1992). Caractérisation de la mobilité des métaux lourds dans les sédiments. Recherches Etudes Environnement Développement, October 1992, 27-33.

Brilhante, O.M. (1990). Magnétisme et diagnostique de la pollution particulaire métallique dans I'environnement. PhD Thesis, Université Paris XII-Val de Marne, France.

Bussy, A.-L. (1993). Relargage des métaux lourds par les sédiments pluviaux. In: Rejets urbains par temps de pluie: pollutions et nuisances, B. Tassin and D.R. Thévenot (Eds.), Les Presses des Ponts, Paris, 95-111.

Chebbo, G. (1992). Solides des rejets pluviaux urbains: caractérisation et traitabilité. PhD Thesis, Ecole Nationale des Ponts et Chaussées.

Colin, F. (1986). The form and fate of metals contained in municipal and mixed sewage with a view to the agricultural use of sewage sludge. European Community Commission report, concerted action cost 681, Ministère Délégué à l'Environnement and Institut de Recherches Hydrologiques, Nancy, France.

Estèbe, A.,Mouchel, J.-M. and Thévenot, D.R. (1993). Impact des orages en zone urbaine sur les 
concentrations métalliques des matières en suspension de la Seine. PIREN-Seine program, group 4, final report 1989-1992.

Estèbe, A. (1993). Paris city and urban runoff impacts of heavy metals on river Seine suspended solids. In: $4^{\text {th }}$ European Postgraduate Workshop on Urban Runoff, Sewer Systems, Treatment Plants and Receiving Waters, Aalborg, Denmark, 5-9 July.

Figura, P. and McDuffie, B. (1977). Characterisation of the calcium form of the Chelex-100 for trace metal studies. Anal. Chem., 49, 1950-1953.

Florence, T.M. (1982). The speciation of trace elements in waters. Talanta, 29, 345-364.

Flores-Rodriguez, J., Lebreton, L., Bussy, A.-L. and Thévenot D.R. (1990). Toxic metal speciation scheme for water and sediment from an urban storm sewage. Proc. $5^{\text {th }}$ Int. Conf. on Urban Storm Drainage, Osaka, Japan, 23-27 July, 457-462.

Flores-Rodriguez, J. (1992). Les métaux toxiques dans les eaux pluviales en milieu urbain: caractéristiques physico-chimiques. PhD Thesis, Université Paris XII-Val de Marne.

Förster, J. (1990). Roof runoff: a source of pollutants in urban storm drainage systems ?. Proc. $5^{\text {th }}$ Int. Conf. on Urban Storm Drainage, Osaka, Japan, 23-27 July, 469-474.

Fraboulet, S., Mulliss, R., Flores-Rodriguez, J., Mouchel, J.-M., Revitt, D.M., Garnier-Zarli, E. and Thévenot, D.R. (1993). The use of metal bioindicators to assess the impact of combined sewer overflows on the River Seine. In: Proc. $6^{\text {th }}$ Int. Conf. on Urban Storm Drainage, J. Marsalek and H.C. Torno (Eds.), Seapoint Publishers, Victoria, B.C., 500-505.

Hémain, J.C. (1984). Mesure de la pollution du ruissellement pluvial urbain. Exploitation des données autres que MES, DCO et DBO5. Rapport 2/84 LHM, Université des Sciences et Techniques du Languedoc.

Kernstem, M. and Förstner, U. (1987). Effect of sample pretreatment on the reliability of solid speciation data of heavy metals - implications for the study of early diagenetic processes. Marine Chemistry, 22, 299-312.

Lebreton, L. and Thévenot, D.R. (1992). Metal pollution release by road aerosols. Envir. Technol., 13, 35-44.

Lebreton, L., Seidl, M., Mouchel, J.-M. and Thévenot, D.R. (1993). Toxic metals in urban runoff; mobility assessment using reactor experiments. In: Proc. $6^{\text {th }}$ lnt. Conf. on Urban Storm Drainage., J. Marsalek and H.C. Torno (Eds.), Seapoint Publishing, Victoria, B.C., 188-193.

Marsalek, J. (1991). Pollutant loads in urban stormwater: review of methods for planning level for planning-level estimates. Water Resources Bulletin, 27, 283-29l.

Martin, J.M., Nirel, P. and Thomas, A.J. (1987). Sequential extraction techniques: promises and problems. Marine Chemistry, 22, 313-341.

Megellati, N. (1982). Mise au point d'un schéma d'extractions sélectives des polluants métalliques associés aux diverses phases constitutives des sédiments. PhD Thesis, Institut Universitaire de Recherche Scientifique, Université de Pau et des pays de l'Adour, France.

Mortison, G.M.P. (1985). Metal speciation in urban runoff. PhD Thesis, Middlesex Polytechnic, Enfield, U.K.

Morrison, G.M.P., Batley, G.E. and Florence, T.M. (1989). Metal speciation and toxicity, Chemistry in Britain, August, 791-796.

Nelson, A. and Donkin, P. (1985). Processes of bioaccumulation: the importance of chemical speciation. Marine Pollution Bulletin, 16, 164-169.

Paffoni, C. (1992). Caractérisation des eaux déversées par temps de pluie à l'usine de Clichy. CRITER SIAAP report.

Pereira-Ramos, L. (1989). Exploitation critique des résultats d'analyses de métaux sur sédiments et bryophytes dans le bassin Seine-Normandie de 1979 à 1988. AFBSN-IHC-Naturalia et Biologia report.

Revitt, D.M. and Morrisson, G.M.P. (1987). Metal speciation variations within separate stormwater systems. Envir. Technol. Letters, 8, 373-380.

Robbe, D. (1984). Interprétation des teneurs en éléments métalliques associés aux sédiments. Ministère de l'Urbanisme et du Logement, Ministère des Transport and Laboratoire Central des Ponts et Chaussées report, Environnement et Génie Urbain (EG-1) series. 
Shutes, R.B., Ellis, J.B. and Revitt. D.M. (1990). Ecotoxicological criteria for the assessment of episodic pollution. in Biological Standards for Water Quality Assessment, Urban Pollution Research Centre report n०19, Middlesex University, London.

S.T.U. (1985). La pollution du ruissellement pluvial urbain. Campagne de mesure expérimentale française 1980-1982. Ministère de I'Urbanisme et du Logement l'eport.

Tessier, A., Campbell, P.G.C. and Bisson, M. (1979). Sequential extraction procedure for the speciation of particulate trace metals. Anal. Chem. 51, 844-851.

Tessier, A., Campbell, P.G.C. and Bisson, M. (1982). Particulate trace metal speciation in stream sediments and relationships with grain size: implications for geochemical exploration. Journal of Geochemical exploration, 176, 77-104.

Tomo, H.C., Marsalek, J. and Desbordes, M. (1985). Urban runoff pollution. NATO ASI Series G. Springer Verlag Publ.

Welté, B. and Montiel A. (1983). Etude des différentes méthodes de spéciation des métaux lourds dans les sédiments. II. Applications. Envir. Technol. L., 4, 223-238.

Wilber, W.G. and Hunter, J.N. (1979). Distribution of metals in street sweepings, storm water solids and urban aquatic sediments. Journal WPCF, 51, 2810-2822. 